\title{
Muscular dystrophy in farm animals : its cause and prevention
}

\author{
By K. L. Blaxter, Hannah Dairy Research Institute, Kirkhill, Ayr
}

Naturally occurring degenerative diseases of the musculature of farm animals are now recognized to be of considerable economic importance. A large number of these diseases has been described and, although most of them give rise to similar clinical syndromes and similar pathological and histopathological changes are found post mortem in the animals concerned, it is certainly not true that they are all due to a single, common nutritional defect. The term 'muscular dystrophy' when applied to farm animals is a particularly wide one and it embraces several distinct diseases which have distinct and complex nutritional aetiologies.

The diseases that can be produced under experimental conditions, other than by the stratagem of importing to the laboratory food from areas where a muscular dystrophy is enzootic, are considered first. Secondly, those naturally occurring muscular dystrophies that have been subject to thorough field investigation are considered and, lastly, some muscular diseases that may have a different aetiology are briefly mentioned.

\section{Experimental muscular dystrophy}

Early work by Slagsvold (I925) suggested that cod-liver oil was toxic for calves and it was later shown that cod-liver oil added to calf diets of skim milk produced severe muscular disease (Blaxter, Watts \& Wood, I952; Blaxter, Wood \& MacDonald, I953). The same disease could be produced in calves by giving them lard as a source of fat, and it could be prevented by giving them very large amounts of $\alpha$-tocopherol in addition to the fats. The production of dystrophy when cod-liver oil was given was shown to be due to a fraction of the oil that contained very highly unsaturated fatty acids (Blaxter, Brown \& MacDonald, I953). Cod-liver oil contains considerable amounts of vitamin $\mathrm{E}$, the range being from about $100 \mathrm{mg} / \mathrm{kg}$ to over $200 \mathrm{mg} / \mathrm{kg}$ (Brown, 1953; Moore, Sharman \& Ward, 1959). Although the tocopherol in cod-liver oil is $\alpha$-tocopherol, the amount present is insufficient to provide protection against the dystrophy-producing effects of highly unsaturated fatty acids.

Effects similar to those found in calves were discovered in other species of farm stock by giving them diets containing unsaturated fats. Molecularly distilled lard produced the disease in lambs (Bacigalupo, Culik, Lueke, Thorp \& Johnston, I952; Draper, James \& Johnson, I952). With pigs, rancid lard was probably responsible for the appearance of muscular dystrophy in the piglets born to sows given diets low in tocopherol (Adamstone, Krider \& James, 1949). Distilled lard was without effect on pigs in shorter experiments by Lannek, Lindberg, Nilsson, Nordström \& Orstadius (I96I) and by Forbes \& Draper (1958). In the Swedish experiments with distilled lard, however, the addition of cod-liver oil to the diet resulted in muscular dystrophy, as indeed it did in the experiments of Garton \& Naftalin (I953).

In addition to lard and cod-liver oil as dystrophogenic fats, maize oil added to a diet of skim milk produced clinical signs and histological lesions of muscular dystrophy in 
calves (Adams, Gullickson, Gander \& Sautter, I959; Adams, Sautter, Gullickson \& Gander, I959). In these experiments giving skim milk alone, or hydrogenation of the maize oil, or addition of tocopherol to the diet containing the maize oil prevented the occurrence of dystrophy. In Sweden, muscular degeneration occurs in pigs given certain cereals in addition to skim milk. Thafvelin (1960) has incriminated the fats of the cereal, which are highly susceptible to oxidative rancidity, as the cause, and in one experiment showed that muscular degeneration could be induced by giving maize oil that had been heated. Linseed oil also appears to be dystrophogenic in the diet of sheep (Marston \& Pierce, 1942). Coconut oil was incriminated as a cause of a muscular weakness in baby pigs occurring in the tropics (Payne, 1959), but muscular degeneration was not confirmed histologically. It is not known whether these effects of unsaturated fats are due to a general effect of unsaturation, to a particular unsaturated fatty acid, or to the formation of particular types of peroxide.

Attempts to produce muscular dystrophy in calves under laboratory conditions by giving diets of very low vitamin $\mathrm{E}$ content and virtually free of fat all show that in the absence of unsaturated fat a very long period on the diet is necessary to produce pathological changes (Maplesden, Harvey \& Branion, 1960; Holter, Smith \& Loosli, I957); indeed in some experiments lasting a few months in which such diets have been given it has proved impossible to produce the disease at all (Adams, Gullickson, Sautter \& Gander, 1954; Blaxter \& McGill, 1955).

There is considerable evidence that certain antioxidants if given every day will prevent the muscular dystrophy of cattle and sheep given diets containing unsaturated fat. In calves, methylene blue is effective in this regard (Blaxter, Brown, Wood \& MacDonald, 1953) and in lambs $N, N^{\prime}$-diphenyl-p-phenylenediamine (DPPD) (Draper \& Johnson, 1956) and ethoxyquin (6-ethoxy-I,2-dihydro-2,2,4trimethylquinoline) (Kuttler \& Marble, 1959). Other antioxidants have not proved fully effective; these include ascorbic acid, butylated hydroxytoluene, butylated hydroxyanisole and ethyl gallate. The muscular degeneration and yellow-fat disease of mink which is induced by fish oils is also prevented by giving methylene blue (Dalgaard-Mikkelsen, Momberg-Jargensen \& Petersen, 1958).

Muscular dystrophy induced by giving unsaturated fats is not prevented by the simultaneous administration of selenium. Welch, Hoekstra, Pope \& Phillips (1960) found that, although dosing of ewes with $\alpha$-tocopherol prevented the dystrophogenic action of fish-liver oil, 0.5 or $4.0 \mathrm{mg} \mathrm{Se} / \mathrm{kg}$ diet had only a slight effect on its incidence. Maplesden \& Loosli ( 1960 ) found that I $\mathrm{mg} \mathrm{Se} / \mathrm{kg}$ diet did not prevent muscular dystrophy produced by calf diets containing cod-liver oil, whereas the addition of $\alpha$-tocopherol did prevent it. Kuttler \& Marble (I960) also found that I mg Se/kg diet did not prevent a muscular disease induced by cod-liver oil in lambs. These results are in marked contrast to those obtained with natural diets in certain areas where muscular dystrophy is enzootic.

\section{Naturally occurring muscular dystrophies}

Muscular dystrophy has been found in cattle and sheep kept under natural conditions in many countries, including all European countries, Russia, Japan, 
New Zealand, Australia, Canada and the United States. It seems to be more common in the northern parts of Europe and America than in the southern parts, but this association may well be fortuitous. The disease assumes epizootic proportions in some countries, whereas in others it appears but seldom and then in single individuals. Whether such isolated cases have an aetiology similar to the enzootic dystrophies is not known.

\section{Enzootic dystrophies}

A muscular dystrophy occurs in NE Scotland in calves suckling their dams (Sharman, 1954). It is associated with feeding the dams on diets that consist largely of turnips and straw and contain about one-tenth of the amount of $\alpha$-tocopherol found in more usual mixed rations (Blaxter, 1957). The disease is not found in calves born to cows kept out-of-doors during the winter and which therefore receive grass, and is very rare in herds that feed on silage. Administration of vitamin $\mathrm{E}$ prevents the disease (Blaxter \& Sharman, r953); the amounts required are, however, very large relative to the amount of vitamin $\mathrm{E}$ consumed by calves in areas where the disease does not occur. The reason is not that the milk produced by cows given the straw and turnip diet contains a high proportion of unsaturated fatty acids thereby increasing the amount of vitamin E required (Garton, Duncan, Blaxter, McGill, Sharman \& Hutcheson, I956).

Experiments have shown that $\mathrm{Se}$ is as effective as is vitamin $\mathrm{E}$ in preventing the disease (Sharman, Blaxter \& Wilson, 1959; Blaxter, McCallum, Wilson, Sharman \& Donald, I96I), and it appears from geochemical evidence that the soils in the area where the disease occurs are derived from arrenaceous sands of the Old Red Sandstone and are deficient in Se. The occurrence of muscular dystrophy in sheep kept in the same area is not common (Marr, Sharman \& Blaxter, 1956).

A disease similar to that in NE Scotland occurs in Oregon, USA (Muth, 1955) and a programme of investigation of this disease and a similar one in lambs has recently been summarized (Schubert, Muth, Oldfield \& Remmert, I96I). The disease can be produced by feeding the dams of the calves on hays native to the area, and there appears to be no relationship between the tocopherol content of the hays and the incidence of the disease. Most of the experimental work has been done with sheep rather than cattle and the results show that either large doses of vitamin $E$ (2000 i.u./lamb at $\mathrm{I}$ and 4 days of age) or administration of Se protects the lambs (Oldfield, Muth \& Schubert, 1960). Earlier work had indicated that vitamin E in smaller amounts was ineffective (Muth, Oldfield, Schubert \& Remmert, r959).

In accounting for variation in the incidence of muscular dystrophy from farm to farm and from year to year, Schubert and his co-workers have pointed out that hays which have produced the disease have had a high sulphur content. Trials in which both sulphate and Se were given suggested that excess sulphate interfered with the prophylactic effect of Se. These observations are of considerable interest in view of Finnish observations that a muscular dystrophy in west Finland is associated with black clay soils very rich in sulphides (Andersson, 1960). In that area the tocopherol content of the forage was low, but not much lower on the affected than on unaffected 
farms (Reinius \& Mäkinen, I 960). No prophylactic trials with vitamin E or Se have, however, been made.

The classical 'stiff lamb disease' of America occurs further to the east and north than the Oregon and Rocky Mountain dystrophies. It occurs in the lambs of ewes given legume hays, beans and barley. It is prevented by administration of vitamin $\mathrm{E}$ (Willman, Loosli, Asdell, Morrison \& Olafson, 1945) and also by Se (Hogue, 1958). There seems little doubt, now that it is known that a sufficient dose of vitamin $\mathrm{E}$ will prevent the Oregon disease, that the stiff lamb disease and the myopathy of lambs in Oregon are in fact the same disease. The Swedish stiff lamb disease (Swahn, Obel \& Wanntorp, I948) also appears closely similar.

Myopathies in both sheep and cattle are common in New Zealand, having been first recognized by Hartley (1953). They develop on pasture supplemented with home-grown forages and are more common in sheep than in cattle. Thus cattle dystrophy has not been recorded from the South Island, whereas it is common in lambs on the stony, silty soils of the Canterbury Plains (Hartley \& Grant, r96r). Several distinct disease syndromes are recognized, classification being based largely on the age incidence of the disease, e.g. 'congenital', 'delayed' or 'hoggett' dystrophy. Vitamin E administration has been shown either to be ineffective or to afford partial protection only. Se administration, on the other hand, results in complete protection. As with the Oregon diseases, the New Zealand diseases occur with diets that contain adequate amounts of vitamin E, as judged by the minimal amounts required by animals kept elsewhere, and it seems that the two diseases may be regarded as of identical origin.

It is of some interest that before the advent of treatment with Se it had been noted on affected farms that the application of fertilizers containing iron controlled the disease (Hickey, $195^{8}$ ). Whether iron was responsible seems doubtful, but it is worth comment that many of those who investigated muscular dystrophies in several countries in the 'pre-selenium' era noted an association of dystrophy incidence with soils of low phosphorus, cobalt and copper content. It seems reasonable to suppose that these soils may have been deficient in Se also.

Two experiments in America, both with sheep, indicate that DPPD, the compound which prevents the experimental disease induced by unsaturated fat, does not prevent enzootic muscular dystrophy (Safford, Swingle \& McRoberts, I956; Hogue, I958). Experiments with other antioxidants have not been made.

\section{Muscular degeneration in pigs}

Ludvigsen (1954, 1955) has described a muscular degeneration very common in Danish pigs and usually noted only at slaughter. The same disease, called 'myopathie exudative dépigmentaire du porc' has been noted in France (Henry, Billon \& Haouza, 1955; Henry, Romani \& Joubert, 1958), it occurs in Holland (Tacken, I952; Zwijhenberg, 1952), and has been reported from this country (Lawrie, r960). Ludvigsen is of the opinion that the disease represents a mild form of the more acute enzootic myopathies described above, but Lawrie (1960) has pointed out that certain of the histopathological changes noted are not common to both diseases. Ludvigsen has 
presented evidence to suggest that the defect in the muscles is a disease of adaptation, in the sense in which this term is used by Selye (1950), and that it has arisen during the genetic improvement of the Danish Landrace pig. It is certainly more common in this improved breed than in others.

\section{Natural myopathies of unknown cause that occur in Britain}

Bosanquet, Daniel \& Parry (r956) drew attention to a myopathy occurring in adult sheep in the Oxford region and claimed that the myopathy was the result of the nervous disease 'scrapie'. This claim was refuted when Hulland (1958) showed that muscular lesions were not present in many sheep with scrapie. Stamp (1960) also has found muscular lesions in adult sheep in the Edinburgh area despite the fact that some of them had been given large amounts of $\alpha$-tocopheryl acetate for 16 months before slaughter. Simple dietary deficiency of vitamin $\mathrm{E}$ thus seems an unlikely cause, but a Se deficiency not responsive to vitamin E remains a possibility. No experimental tests have yet been made to substantiate the latter hypothesis.

A congenital muscular degeneration in newborn lambs has been described by Roberts (r929) from Wales and by Nisbet \& Renwick (196I) from Scotland. The lesions resemble those of the naturally occurring dystrophies but are usually limited to the longissimus cervicus muscle, and the lambs usually recover spontaneously. The lesion is possibly the result of a primary ischaemia after prolonged labour, and is mentioned here because it is the only myopathy in sheep or cattle for which a genetic origin has been postulated. This is in marked contradistinction to the muscular dystrophies of man, which appear to be of genetic origin.

\section{Conclusions}

It seems well established that most of the enzootic muscular dystrophies in sheep and cattle are prevented by administration either of small amounts of Se or of amounts of $\alpha$-tocopherol very large relative to the presumptive need of vitamin $\mathrm{E}$. by the animal. It is also evident that muscular diseases induced experimentally in farm stock by giving diets containing unsaturated fats, though they can be prevented by giving large amounts of $\alpha$-tocopherol, cannot be prevented by giving Se. The latter observations agree with most of the observations on the production of muscular disease in laboratory animals, for the diets have usually contained unsaturated fat and been low in vitamin E content. Certain synthetic antioxidants can prevent the disease induced by unsaturated fat, but one at least (DPPD) has been found ineffective in preventing the natural disease. These findings suggest that, though the pathological changes in the experimental and enzootic diseases are identical, their primary biochemical genesis may be quite different. Finally, certain muscle diseases in pigs and sheep and isolated cases of muscle disease in cattle, sheep and pigs cannot necessarily be attributed to the same aetiological factors as those responsible for the enzootic and experimental diseases.

\section{REFERENCES}

Adams, R. S., Gullickson, T. W., Gander, J. E. \& Sautter, J. H. (1959). Y. Dairy Sci. 42, 1552. Adams, R. S., Gullickson, T. W., Sautter, J. H. \& Gander, J. E. (1954). I. Dairy Sci. 37, 655. 
Adams, R. S., Sautter, J. H., Gullickson, T. W. \& Gander, J. E. (1959). F. Dairy Sci. 42, 1580.

Adamstone, F. B., Krider, J. L. \& James, M. F. (1949). Ann. N.Y. Acad. Sci. 52, 260.

Andersson, P. (1960). Acta path. microbiol. scand. Suppl. no. I34.

Bacigalupo, F. A., Culik, R., Lueke, R. W., Thorp, F. \& Johnston, R. L. (1952). J. Anim. Sci. rr, 609.

Blaxter, K. L. (I957). Vet. Rec. 69, II 5 O.

Blaxter, K. L., Brown, F. \& MacDonald, A. M. (1953). Brit. F. Nutr. 7, 287.

Blaxter, K. L., Brown, F., Wood, W. A. \& MacDonald, A. M. (1953). Brit. F. Nutr. 7, 337.

Blaxter, K. L., McCallum, E. S. R., Wilson, R. S., Sharman, G. A. M. \& Donald, L. G. (1961). Proc. Nutr. Soc. 20, vi.

Blaxter, K. L. \& McGill, R. F. (1955), Vet. Rev. Annot. 1, 91.

Blaxter, K. L. \& Sharman, G. A. M. (1953). Nature, Lond., 172, 1006.

Blaxter, K. L., Watts, P. S. \& Wood, W. A. (1952). Brit. F. Nutr. 6, 125.

Blaxter, K. L., Wood, W. A. \& MacDonald, A. M. (I953). Brit. \%. Nutr. 7, 34.

Bosanquet, F. D., Daniel, P. M. \& Parry, H. B. (1956). Lancet, 271, 737.

Brown, F. (1953). Nature, Lond., r7r, 790.

Dalgaard-Mikkelsen, S., Momberg-Jørgensen, H. C. \& Petersen, F. H. (1958). Beretn. Forsøgslab. $K b h$, no. 308.

Draper, H. H., James, M. F. \& Johnson, B. C. (r952). I. Nutr. 47, $5^{83}$.

Draper, H. H. \& Johnson, B. C. (1956). F. Anim. Sci. 15, I 154.

Forbes, R. M. \& Draper, H. H. (1958). F. Nutr. 65, 535.

Garton, G. A., Duncan, W. R. H., Blaxter, K. L., McGill, R. F., Sharman, G. A. M. \& Hutcheson, M. K. (1956). Nature, Lond., 177, 792.

Garton, G. A. \& Naftalin, J M. (1953). Vet. Rec. 65, 262.

Hartley, W. J. (1953). N.Z. vet. F. I, 137.

Hartley, W. J. \& Grant, A. B. (I96I). Fed. Proc. 20, 679.

Henry, M., Billon, J. \& Haouza, G. (I955). Rev. Path. comp. no. 669, p. 857.

Henry, M., Romani, J.-D. \& Joubert, L. (1958). Rev. Path. gén. no. 696, p. 355.

Hickey, F. (1958). N.Z. Agriculturalist, II, 3.

Hogue, D. E. (1958). F. Amer. vet. med. Ass. 133, 568.

Holter, J. A., Smith, A. M. \& Loosli, J. K. (1957). Unpublished experiments reported by Maplesden \& Loosli (I960).

Hulland, T. J. (r958). F. comp. Path. 68, 264.

Kuttler, K. L. \& Marble, D. W. (1959). Cornell Vet. 49, I83.

Kuttler, K. L. \& Marble, D. W. (1960). Amer. F. vet. Res. 21, 437.

Lannek, N., Lindberg, P., Nilsson, G., Nordström, G. \& Orstadius, K. (I96r). Res. vet. Sci. 2, 67.

Lawrie, R. A. (1960). F. comp. Path. 70, 273 .

Ludvigsen, J. (1954). Beretn. Forsggslab. Kbh. no. 272.

Ludvigsen, J. (1955). Beretn. Forsagslab. Kbh. no. 282.

Maplesden, D. G., Harvey, J. D. \& Branion, H. D. (rg6o). Canad. vet. F. r, ro.

Maplesden, D. C. \& Loosli, J. K. (1 960). F. Dairy Sci. 43, 645.

Marr, T. G., Sharman, G. A. M. \& Blaxter, K. L. (1956). Vet. Rec. 68, 408.

Marston, H. R. \& Pierce, A. W. (1942). Australian vet. $\mathcal{~}$. 8, 63.

Moore, T., Sharman, I. M. \& Ward, R. J. (1959). Brit. F. Nutr. 13, 100.

Muth, O. H. (1955). F. Amer. vet. med. Ass. 126, 355.

Muth, O. H., Oldfield, J. E., Schubert, J. R. \& Remmert, L. F. (1959). Amer. F. vet. Res. 20, 23 I.

Nisbet, D. I. \& Renwick, C. C. (I96I). F. comp. Path. 7I, 177.

Oldfield, J. E., Muth, O. H. \& Schubert, J. R. (1960). Proc. Soc, exp. Biol, N.Y., 103, 799.

Payne, W. J. A. (1959). Nature, Lond., r83,828.

Reinius, L. \& Mäkinen, V. (1960). Nord. VetMed. 12, 563.

Roberts, J. A. F. (1929). F. Genet. 21, 57.

Safford, J. W., Swingle, K. F. \& McRoberts, D. E. (1956). Amer. F. vet. Res. 17, 503.

Schubert, J. R., Muth, O. H., Oldfield, J. E. \& Remmert, L. F. (I96I). Fed. Proc. 20, 689.

Selye, H. (1950). The Physiology and Pathology of Exposure to Stress. Montreal: Acta Inc.

Sharman, G. A. M. (1954). Vet. Rec. 66, 275 .

Sharman, G. A. M., Blaxter, K. L. \& Wilson, R. S. (1959). Vet. Rec. 7r, 536.

Slagsvold, L. (1925). Norsk. VetTidsskr. 6, I6I.

Stamp, J. T. (1960). F. comp. Path. 70, 296.

Swahn, O., Obel, A. L. \& Wanntorp, H. (1948). Skand. VetTidskr. 38, 129.

Tacken, P. H. W. (1952). Tijdschr. Diergeneesk. 77, 487.

Thafvelin, B. (1960). Nature, Lond., 188, i 169 .

Welch, J. G., Hoekstra, W. G., Pope, A. I. \& Phillips, P. H. (1960). F. Anim. Sci. rg, 620.

Willman, J. P., Loosli, J. K., Asdell, S. A., Morrison, F. B. \& Olafson, P. (1945). F. Anim. Sci, 4, 128.

Zwijhenberg, H. A. (1952). Vlaam. Diergeneesk. Tijdschr. 21, 25. 